Fourth International Conference on Sustainable Construction Materials and Technologies

http://www.claisse.info/Proceedings.htm

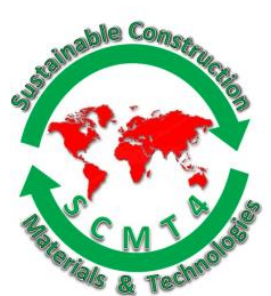

SCMT4

Las Vegas, USA, August 7-11, 2016

\title{
Behavior of Recycled Construction Material Concrete Against Elevated Temperatures
}

\author{
Zaineb Aamer Shamsulddin ${ }^{1}$ \\ ${ }^{1}$ PhD, Assistant Professor at College of Engineering, Al-Iraqia University, Baghdad, Iraq, \\ Email: <zainebaamer@yahoo.com>
}

\begin{abstract}
The main purpose of this research is to study the behavior of recycled concrete as a partial replacement of coarse aggregate against elevated temperatures. $(10,20,30,40) \%$ by weight was used for recycled concrete. Concrete samples exposed to temperatures $(32,250,500){ }^{\circ} \mathrm{C}$ for six hours. Mechanical tests such as compressive and tensile strength tests, physical tests such as ultrasonic pulse velocity, bulk density, porosity, specific gravity and water absorption tests were done to the samples after curing in normal water for 28 days and for samples exposed to elevated temperatures. Test results showed slightly degradation in mechanical and physical engineering properties of concrete specimens that cured in normal water, degradation increased with increasing of replacement but test results still closely to reference samples. Noticeable deterioration showed in mechanical and physical properties for both reference and partial replacement samples at $(250,500){ }^{\circ} \mathrm{C}$.
\end{abstract}

\section{INTRODUCTION}

Rapid industrial development causes serious problems all over the world such as depletion of natural aggregates and creates enormous amounts of waste materials from construction and demolition activities. One of the ways to reduce this problem is to utilize recycled concrete aggregate in the production of concrete [Young and Teo 2009]. The compressive strength of natural aggregate concrete is highest among other types of recycled aggregate concrete. RAC has approximately 19\% lower cube compressive strength. Reduction in compressive strength observed in the ranges $21 \%$ to $61 \%$ for elevated temperatures $(200,400$, 600 and 800) ${ }^{\circ} \mathrm{C}$ for six hours [Arundeb et al. 2012]. Concrete in the temperature range $(20-200){ }^{\circ} \mathrm{C}$ can show a small strength loss. Regain of strength is observed between(120 and 300) ${ }^{\circ} \mathrm{C}$ and is attributed to greater Van der Waals forces as a result of cement gel layers moving closer to each other. Beyond $350^{\circ} \mathrm{C} \mathrm{a}$ rapid decrease in strength was happened [Naus 2006]. Fired recycled coarse aggregate at fire temperatures (300, 600 and 800) ${ }^{\circ} \mathrm{C}$ for two hours was used as a partial replacement of coarse aggregate. The results indicated that the recycled coarse aggregate subjected to fire can successfully use for structural concrete [Fahmy et al. 2012]. The rate of heat increases with increase of concrete's compressive strength for both (RAC) recycled aggregate concrete and normal aggregate concrete columns (450*450) $\mathrm{mm}$. Under the same initial axial force ratio, those with lower compressive strength demonstrate better fire resistance performance at $(200,400,600,800$ and 1000$){ }^{\circ} \mathrm{C}$. The fire resistance performance of RAC columns is better than that of normal concrete columns with the same compressive strength [Hongying et al. 2014]. Natural concrete aggregate was replaced with $(0,50$ and 100) \% concrete tile aggregate and subjected to (200 and 
400) ${ }^{\circ} \mathrm{C}$. The results showed decrease of compressive and tensile strength when increase the temperature. Compared to conventional concrete, the strength of concrete tile aggregate also decreases with increase in temperature but the difference in decrease of compressive strength of natural concrete aggregate is higher than concrete tile aggregate [Maya and Nivin 2014]. The results of research studies show that when recycled aggregates obtained from crushed concrete are used to replace up to $20 \%$ by weight of coarse natural aggregate in concrete little effect on the properties of concrete is noticed. It was noted, the best performance in terms of carbonation was for concretes with recycled aggregate content of between $20 \%$ and $50 \%$ by mass [Parekh and Modhera 2011]. Concrete compressive strength depends on the quantity of recycled coarse aggregate (RCA). Increasing the quantity of RCA up to $100 \%$ increased the concrete compressive strength up to $25 \%$ in these tests. RCA concrete shouldn't be used for structures exposed to aggressive environment conditions without appropriate previous testing [Maleŝev et al. 2010]. Salau et al. [2015] discussed the effect of heating temperatures $(200,400 \text { and } 600)^{\circ} \mathrm{C}$ for two hours on concrete with natural coarse aggregate and partially replacement with recycled coarse aggregate in ratios of $(0,15$ and $30) \%$. There was initial drop in strength from (100 to 200) ${ }^{\circ} \mathrm{C}$ due to relatively weak interfacial bond between recycled coarse aggregate and hardened paste within concrete matrix; a gradual increase in strength continued from $(200-450)^{\circ} \mathrm{C}$ and a steady drop occurred again as it approach $600^{\circ} \mathrm{C}$. Arundeb et al. [2012] investigated the mechanical and micro structural properties of recycled aggregate concrete with uncoated and geopolymer cement coated recycled aggregate exposed to elevated temperatures $(400,600 \text { and } 800)^{\circ} \mathrm{C}$ for six hours. The reduction in compressive strength was observed (23.4 to 50.3) \%. In general natural aggregate concrete performs better than recycled aggregate concrete with coated or uncoated recycled aggregate, including samples exposed to elevated temperatures. Coated RAC showed higher compressive strength compared to uncoated RAC when exposed to different elevated temperatures. Vieira et al. [2011] presented results of an experimental study on the residual mechanical performance of concrete produced with recycled coarse aggregates, after being subjected to high temperatures. A reference concrete made with natural coarse aggregate and three concrete mixes with replacement rates of (20,50 and 100)\% of natural coarse aggregates by recycled concrete coarse aggregates. Specimens were exposed of $1 \mathrm{~h}$ to temperatures of $(400,600$ and 800$){ }^{\circ} \mathrm{C}$. Results showed that there are no significant differences in the thermal response and post- fire mechanical behavior of concrete made with recycled coarse aggregates, when compared to conventional concrete. Tabsh and Abdlfatah [2009] investigated the strength of concrete made with recycled concrete coarse aggregate. The results showed that compressive strength of recycled concrete can be (10-25) \% lower than that of conventional concrete made with natural coarse aggregate. Kwan et al. [2012] observed at his study that the physical and mechanical properties of recycled concrete aggregates replacements up to $80 \%$ are good results for UPV, compressive strength. Low water absorption less than $3 \%$ for RCA replacement up to $30 \%$.Tests are done for reference concrete samples and $(15,30$, $60,80) \%$ recycled coarse aggregate replacements.

\section{EXPERIMENTAL INVESTIGATION}

\section{Materials}

Cement. Local ordinary Portland cement type (I) was used in the mixes. Chemical and physical tests of cement are illustrated in Tables $(1,2)$. The results showed that cement chemical analysis specify ASTM C114-07

Sand. Local sand was used as a fine aggregate in all mixes, sieve analysis test results illustrated in Table 3 and specify ASTM C136 -01. Laboratory tests showed that specific gravity, water absorption and sulfates contents for fine aggregate are $(2.6,1.6 \%$ and $0.27 \%)$ respectively.

Coarse aggregate. Local gravel was used as a coarse aggregate and specify ASTM C136 -01 with maximum grain size $10 \mathrm{~mm}$. Laboratory tests showed that specific gravity, water absorption and sulfates contents for coarse aggregate are $(2.64,0.9 \%$ and $0.07 \%)$ respectively. 
Crushed concrete. Reference concrete samples were crushed and used as a partial replacement recycled coarse aggregate $(10,20,30,40) \%$ by weight with maximum grain size $10 \mathrm{~mm}$.

\section{Materials preparations}

Concrete mixture. Concrete prepared for reference samples with mix proportion 1:2:4 (C: S: G) by weight and w/c ratio 0.5 to obtain slump equal to $40 \mathrm{~mm}$ ASTM C143-01.

Recycled concrete. Reference concrete samples were reused as recycled coarse aggregates after crushing and sieving in proportions $(10,20,30$ and 40$) \%$ by weight of coarse aggregate. Concrete mix proportion is $1: 2: 4(\mathrm{C}: \mathrm{S}: \mathrm{G} \& \mathrm{RCA})$ with w/c 0.52 to obtain slump equal to $40 \mathrm{~mm}$ ASTM C143-01.

\section{Samples casting and curing}

Steel cubes with $150 \mathrm{~mm}$ size and steel prisms $(400 * 100 * 100) \mathrm{mm}$ size were used to cast concrete specimens. Perfect compaction was achieved by using compacting vibrating table; concrete surface was leveled and covered by using polyethylene sheet for 24 hours in ambient laboratory temperature $32^{\circ} \mathrm{C}$. Specimens cured in drinking water for 28 days and used in this experimental study. (See figure 1 and 2 ).

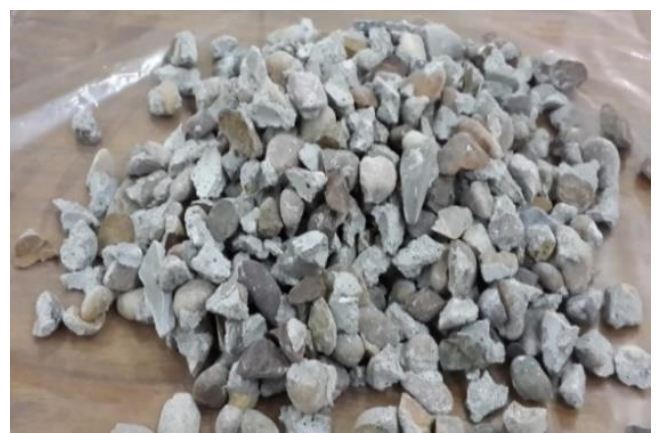

Figure 1. Recycled Concrete Aggregate (RCA)

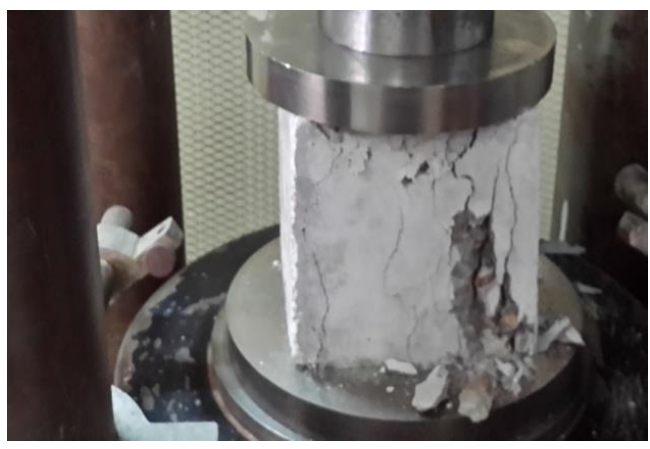

Figure 2. Compressive strength test

Table 1. Chemical analysis of cement

\begin{tabular}{|c|c|}
\hline Compound Type & (Results)\% \\
\hline $\mathrm{SiO}_{2}$ & 21.82 \\
\hline $\mathrm{Al}_{2} \mathrm{O}_{3}$ & 3.55 \\
\hline $\mathrm{Fe}_{2} \mathrm{O}_{3}$ & 4.2 \\
\hline $\mathrm{CaO}$ & 62.32 \\
\hline $\mathrm{MgO}$ & 2.13 \\
\hline $\mathrm{SO}_{3}$ & 2.48 \\
\hline $\mathrm{L} . \mathrm{O} . \mathrm{I}$ & 1.83 \\
\hline $\mathrm{I} . \mathrm{R}$ & 0.65 \\
\hline $\mathrm{L} . \mathrm{S} . \mathrm{R}$ & 0.9 \\
\hline $\mathrm{C}_{3} \mathrm{~A}$ & 2.3 \\
\hline $\mathrm{C}_{3} \mathrm{~S}$ & 24.25 \\
\hline & \\
\hline
\end{tabular}


Table 2. Physical properties of cement

\begin{tabular}{|c|c|}
\hline Properties & Results \\
\hline Initial setting time & $122 \mathrm{~min}$. \\
\hline Final setting time & $176 \mathrm{~min}$. \\
\hline Soundness & $1 \mathrm{~mm}$ \\
\hline Compressive strength at 3 days & $26.6 \mathrm{~N} / \mathrm{mm}^{2}$ \\
\hline Compressive strength at 7 days & $43 \mathrm{~N} / \mathrm{mm}^{2}$ \\
\hline
\end{tabular}

Table 3. Sieve analysis of sand

\begin{tabular}{|c|c|}
\hline Sieve Size (mm) & Passing (\%) \\
\hline 9.5 & 100 \\
\hline 4.75 & 95 \\
\hline 2.36 & 93 \\
\hline 1.18 & 79 \\
\hline 0.6 & 61 \\
\hline 0.3 & 28 \\
\hline 0.15 & 0 \\
\hline
\end{tabular}

\section{Samples mechanical and physical tests}

Compressive strength. This test was done according to BS 1881: part 116- 1983 for concrete cubes and the results represent average results of two cubes.

Tensile strength. This test was done according to ASTM C293-02 for concrete prisms $(400 * 100 * 100) \mathrm{mm}$ and the results represent average results of two prisms.

Ultrasonic pulse velocity. This test was done according to ASTM C597-02 for concrete cubes and the results represent average results of two cubes.

Bulk density. This test was done according to ASTM C642-97 for concrete cubes and the results represent average results of two cubes.

Apparent specific gravity. This test was done according to ASTM C642-97 for concrete cubes and the results represent average results of two cubes.

Apparent porosity. This test was done according to ASTM C642-97 for concrete cubes and the results represent average results of two cubes.

Water absorption. This test was done according to ASTM C642-97 for concrete cubes and the results represent average results of two cubes.

Slump test. This test was done according to ASTM C143-01 for all concrete mixtures and the average result equal to $40 \mathrm{~mm}$. 


\section{RESULTS AND DISCUSSIONS}

Compressive and flexural tensile strength. The results at ambient temperature (32) ${ }^{\circ} \mathrm{C}$ indicated that compressive and flexural tensile strength for reference concrete samples with ordinary (natural) aggregate higher than for concrete with different recycled concrete aggregates proportions. Maximum cube compressive strength is $31.3 \mathrm{MPa}$ and flexural tensile strength is $4.5 \mathrm{MPa}$ for reference samples and decrease when increase the addition percentage of recycled concrete aggregate replacement in amounts (10, $20,30,40) \%$. Cube compressive strength and flexural tensile strength test results range respectively between $30.66 \mathrm{MPa}, 4.2 \mathrm{MPa}$ for $10 \%$ replacement to $24.22 \mathrm{MPa}, 2.7 \mathrm{MPa}$ for $40 \%$ replacement as shown in Tables 4, 5 and figure 3. The reduction in compressive and flexural tensile strength may be due to a poor bond between cement paste and recycled aggregate particles which contain hydrated cement paste particles. The results at elevated temperatures (250 and 500) ${ }^{\circ} \mathrm{C}$ showed degradation in compressive and flexural tensile strength for all samples with natural and recycled coarse aggregate. Compressive strength decreased to $22.4 \mathrm{MPa}$ at $(250){ }^{\circ} \mathrm{C}$ and $21.1 \mathrm{MPa}$ at $(500){ }^{\circ} \mathrm{C}$ for reference samples and degradation in compressive and flexural tensile strength increased with increasing recycled concrete coarse aggregate replacement.

Table 4. Compressive strength of concrete samples $\left(\mathrm{N} / \mathrm{mm}^{2}\right)$

\begin{tabular}{|c|c|c|c|}
\hline Type of Test & $\begin{array}{c}\text { Compressive Strength } \\
\text { at } 32^{\circ} \mathrm{C}(\mathrm{MPa})\end{array}$ & $\begin{array}{c}\text { Compressive } \\
\text { Strength at } \\
250^{\circ} \mathrm{C}(\mathrm{MPa})\end{array}$ & $\begin{array}{c}\text { Compressive } \\
\text { Strength at } 500^{\circ} \mathrm{C} \\
(\mathrm{MPa})\end{array}$ \\
\hline Reference concrete & 31.3 & 22.4 & 21.1 \\
\hline $10 \%$ RC Replacement & 30.66 & 21.6 & 19.8 \\
\hline $20 \%$ RC Replacement & 29.2 & 20.1 & 18.5 \\
\hline $30 \%$ RC Replacement & 27.6 & 18.6 & 16.4 \\
\hline $40 \%$ RC Replacement & 24.2 & 15.4 & 12.7 \\
\hline
\end{tabular}

Table 5. Flexural tensile strength of concrete samples $\left(\mathrm{N} / \mathrm{mm}^{2}\right)$

\begin{tabular}{|c|c|c|c|}
\hline Type of Test & $\begin{array}{c}\text { Flexural tensile at } \\
32^{\circ} \mathrm{C}(\mathrm{MPa})\end{array}$ & $\begin{array}{c}\text { Flexural tensile } \\
\text { at } 250^{\circ} \mathrm{C}(\mathrm{MPa})\end{array}$ & $\begin{array}{c}\text { Flexural tensile at } \\
500^{\circ} \mathrm{C}(\mathrm{MPa})\end{array}$ \\
\hline Type of Samples & 4.5 & 3.9 & 3.5 \\
\hline Reference concrete & 4.2 & 3.5 & 3.2 \\
\hline $20 \%$ RC Replacement & 3.9 & 3.1 & 2.8 \\
\hline $30 \%$ RC Replacement & 3.3 & 2.5 & 2.1 \\
\hline $40 \%$ RC Replacement & 2.7 & 1.9 & 1.5 \\
\hline
\end{tabular}

Compressive strength is a major indicator for many physical properties of concrete such as UPV, bulk density, apparent specific gravity, porosity and water absorption. Increase compressive strength value means increase the bulk density, specific gravity and UPV values and decrease the porosity and water absorption percentage.

Ultrasonic pulse velocity. At ambient temperatures, UPV test results are $5.41 \mathrm{~km} / \mathrm{sec}$ for reference samples and range between $(5.37-5.06) \mathrm{km} / \mathrm{sec}$ for recycled concrete aggregate replacement in proportions (1040) $\%$. At $250^{\circ} \mathrm{C}$ UPV test results decrease from $3.67 \mathrm{~km} / \mathrm{sec}$. for reference samples to $3.2 \mathrm{~km} / \mathrm{sec}$. for $40 \%$ recycled concrete aggregate replacement.. At $500^{\circ} \mathrm{C}$ UPV test results decrease from $3.3 \mathrm{~km} / \mathrm{sec}$. for 
reference samples to $2.2 \mathrm{~km} / \mathrm{sec}$. for $40 \%$ recycled concrete aggregate replacement.. as shown in Table 6 and figure 4.

Bulk density. Bulk density test results are $2.309 \mathrm{gm} / \mathrm{cm}^{3}$ for reference samples and range between $(2.302-2.22) \mathrm{gm} / \mathrm{cm}^{3}$ for recycled concrete aggregate replacement in proportions (10$40) \%$. Bulk density decrease with increasing elevated temperature and recycled concrete coarse aggregate replacement as shown in Table7.

Water Absorption. Water Absorption test results are $3.972 \%$ for reference samples and range between (3.977 - 3.991) \%for recycled concrete aggregate replacement in proportions (10-40) $\%$. Water Absorption increase with increasing elevated temperature and recycled concrete coarse aggregate replacement as shown in Table8.

Specific gravity. Specific Gravity test results are 2.538 for reference samples and range between $(2.528-2.490) \%$ for recycled concrete aggregate replacement in proportions (10-40) $\%$. Specific gravity decrease with increasing elevated temperature and recycled concrete coarse aggregate replacement as shown in Table 9.

Porosity. Porosity test results are $8.993 \%$ for reference samples and range between $(9.370$ 11.20) \%for recycled concrete aggregate replacement in proportions (10-40) \%. Porosity increase with increasing elevated temperature and recycled concrete coarse aggregate replacement as shown in Table10.

Table 6. U.P.V. of concrete samples $(\mathrm{km} / \mathrm{sec})$

\begin{tabular}{|c|c|c|c|}
\hline Type of Test & $\begin{array}{c}\text { U.P.V. }(\mathrm{km} / \mathrm{sec}) \text { at } \\
32^{\circ} \mathrm{C}\end{array}$ & $\begin{array}{c}\text { U.P.V. }(\mathrm{km} / \mathrm{sec}) \\
\text { at } 250^{\circ}\end{array}$ & $\begin{array}{c}\text { U.P.V. }(\mathrm{km} / \mathrm{sec}) \text { at } \\
500^{\circ} \mathrm{C}\end{array}$ \\
\hline Type of Samples & 5.41 & 3.67 & 3.3 \\
\hline Reference concrete & 5.37 & 3.58 & 3.15 \\
\hline $20 \%$ RC Replacement & 5.3 & 3.52 & 3 \\
\hline $30 \%$ RC Replacement & 5.2 & 3.34 & 2.9 \\
\hline $40 \%$ RC Replacement & 5.06 & 3.2 & 2.2 \\
\hline
\end{tabular}

Table 7. Bulk Density of concrete samples (gm/cm3)

\begin{tabular}{|c|c|c|c|}
\hline Type of Test & $\begin{array}{c}\text { Bulk Density }(\mathrm{gm} / \mathrm{cm} 3) \\
\text { at } 32^{\circ} \mathrm{C}\end{array}$ & $\begin{array}{c}\text { Bulk Density } \\
(\mathrm{gm} / \mathrm{cm} 3) \text { at } \\
250^{\circ} \mathrm{C}\end{array}$ & $\begin{array}{c}\text { Bulk Density } \\
(\mathrm{gm} / \mathrm{cm} 3) \text { at } 500^{\circ} \mathrm{C}\end{array}$ \\
\hline Reference concrete & 2.309 & 2.27 & 2.19 \\
\hline $10 \%$ RC Replacement & 2.302 & 2.21 & 2.1 \\
\hline $20 \%$ RC Replacement & 2.278 & 2.13 & 1.86 \\
\hline $30 \%$ RC Replacement & 2.250 & 2.03 & 1.5 \\
\hline $40 \%$ RC Replacement & 2.22 & 1.8 & \\
\hline
\end{tabular}


Table 8. Water Absorption of concrete samples (\%)

\begin{tabular}{|c|c|c|c|}
\hline Type of Test & $\begin{array}{c}\text { Water Absorption (\%) } \\
\text { at } 32^{\circ} \mathrm{C}\end{array}$ & $\begin{array}{c}\text { Water } \\
\text { Absorption }(\%) \\
\text { at } 250^{\circ} \mathrm{C}\end{array}$ & $\begin{array}{c}\text { Water Absorption (\%) } \\
\text { at } 500^{\circ} \mathrm{C}\end{array}$ \\
\hline Type of Samples & 3.972 & 3.99 & 4.05 \\
\hline $10 \%$ RC Replacement & 3.977 & 4.03 & 4.11 \\
\hline $20 \%$ RC Replacement & 3.981 & 4.09 & 4.19 \\
\hline $30 \%$ RC Replacement & 3.987 & 4.1 & 4.25 \\
\hline $40 \%$ RC Replacement & 3.991 & 4.25 & 4.4 \\
\hline
\end{tabular}

Table 9. Specific Gravity of concrete samples

\begin{tabular}{|c|c|c|c|}
\hline Type of Test & $\begin{array}{c}\text { Specific Gravity at } \\
32^{\circ} \mathrm{C}\end{array}$ & $\begin{array}{c}\text { Specific Gravity } \\
\text { at } 250^{\circ} \mathrm{C}\end{array}$ & $\begin{array}{c}\text { Specific Gravity at } \\
500^{\circ} \mathrm{C}\end{array}$ \\
\hline Type of Samples & 2.538 & 2.40 & 2.25 \\
\hline Reference concrete & 2.528 & 2.37 & 2.18 \\
\hline $10 \%$ RC Replacement & 2.52 & 2.20 & 1.90 \\
\hline $20 \%$ RC Replacement & 2.50 & 1.98 & 1.70 \\
\hline $30 \%$ RC Replacement & 2.49 & 1.60 & 1.37 \\
\hline $40 \%$ RC Replacement & \multicolumn{2}{|c|}{} \\
\hline
\end{tabular}

Table 10. Porosity of concrete samples (\%)

\begin{tabular}{|c|c|c|c|}
\hline Type of Test & Porosity (\%) at $32^{\circ} \mathrm{C}$ & $\begin{array}{c}\text { Porosity (\%) at } \\
250^{\circ} \mathrm{C}\end{array}$ & $\begin{array}{c}\text { Porosity (\%) at } \\
500^{\circ} \mathrm{C}\end{array}$ \\
\hline Type of Samples & 8.993 & 9.03 & 9.10 \\
\hline Reference concrete & 9.370 & 9.45 & 9.65 \\
\hline $20 \%$ RC Replacement & 10.678 & 10.80 & 11.1 \\
\hline $30 \%$ RC Replacement & 10.98 & 11.38 & 11.65 \\
\hline $40 \%$ RC Replacement & 11.2 & 11.7 & 12.36 \\
\hline
\end{tabular}

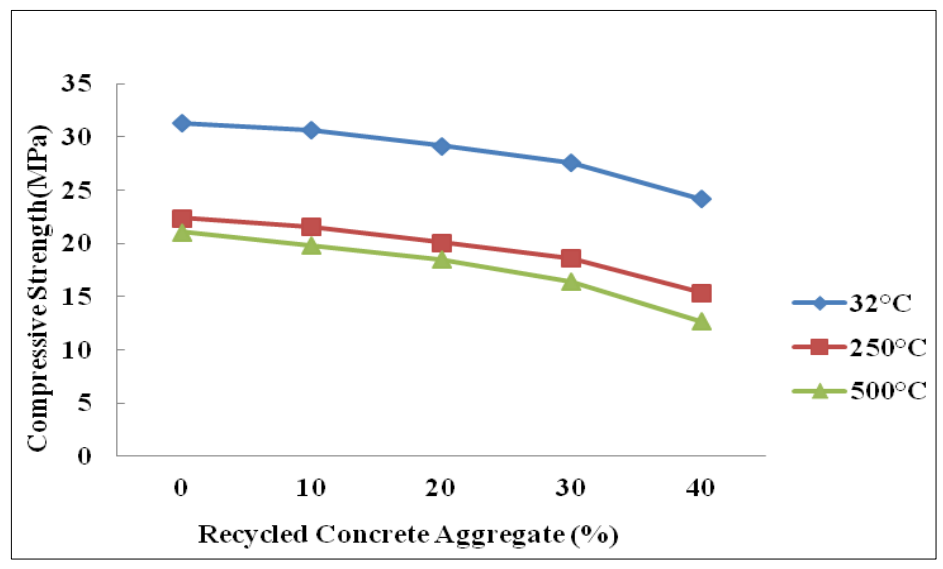

Figure 3. Compressive Strength results 


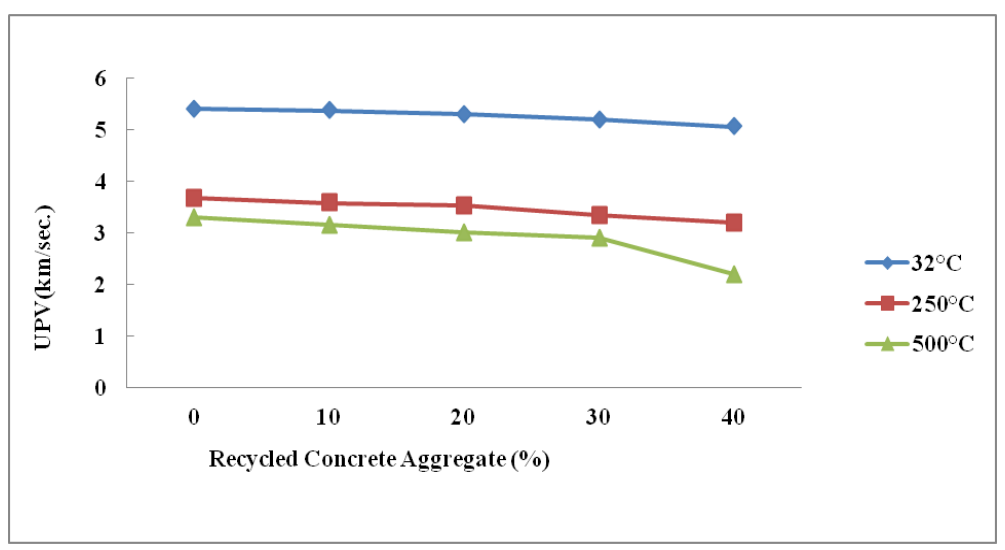

Figure 4. UPV results

\section{CONCLUSION}

- At ambient temperature, using of recycled concrete as a partial coarse aggregate replacement in proportions $(10,20$, and 30$) \%$ gives a best mechanical and physical properties test results. The results are close to reference concrete samples results but $40 \%$ recycled concrete replacement results are differs from reference samples results.

- At (250 and 500) ${ }^{\circ} \mathrm{C}$, using of recycled concrete as a partial coarse aggregate replacement in proportions (10, and 20) \% gives good mechanical and physical properties test results. The results are close to reference concrete samples results.

- At (250 and 500) ${ }^{\circ} \mathrm{C}$, regardless using of recycled concrete as a partial coarse aggregate replacement in proportions (30 and 40) \% gives a bad mechanical and physical properties test results. The results are sharply differs from reference concrete samples results.

\section{REFERENCES}

American Society for Testing and Materials C114, (2007), "Standard Test Methods for Chemical Analysis of Hydraulic Cement," 32 pages.

American Society for Testing and Materials C136, (2001), "Standard Test Method for Sieve Analysis of Fine and Coarse Aggregates," 5 pages.

American Society for Testing and Materials C143, (2001), "Standard Test Method for Flow of Hydraulic Cement Mortar," 2 pages.

American Society for Testing and Materials C597, (2002), "Standard Test Method for Pulse Velocity through Concrete," 4 pages.

American Society for Testing and Materials C 642, (1997), "Standard Test Method for Density, Absorption and Voids in Hardened Concrete," 3 pages.

American Society for Testing and Materials C 293, (2002), "Standard Test Method for Flexural Strength of Concrete (Using Simple Beam with Center - Point Loading)," 3 pages. 
Arundeb, G., Saroj, M. and Somnath, G., (2012), "Recycled Aggregate Concrete Exposed to Elevated Temperature," Engineering and Applied Sciences, 7(1), 100-107.

Arundeb, G., Saroj, M. and Somnath, G., (2012), "Coated Recycled Aggregate Concrete Exposed to Elevated Temperature," Global Journal of Researches in Engineering, 12(3), 27-31.

British Standard BS 1881: Part 116: 1983, "Method for Determination of Compressive Strength

Fahmy, W.S., Heniedy, E.A. and Ali, E.E., (2012), "Performance of Concrete Containing Crushed Waste Concrete Exposed to Different Fire Temperature," International Journal of Civil and Structural Engineering, 3(1), 9-22.

Hongying, D., Wanlin, C., Jianhui, B., and Jianwei, Z., (2014), "The Fire Resistance Performance of Recycled Aggregate Concrete Columns With Different Concrete Compressive Strength" www.mdpi.com/journal/material, 7843-7860.

Kwan, W. H., Ramli, M., and Sulieman, M. Z., (2012), Influence of the Amount of Recycled Coarse Aggregate in Concrete Design and Durability Properties, Cement and Concrete Research, 26(1), 565573.

Malesev, M., Radonjanin, V., and Marinkovic, S., (2010), "Recycled Concrete as Aggregate for Structural Concrete Production," Sustainability Journal,www.mdpi.com/journal/sustainability, 1204 - 1225.

Maya, T. M., and Philip, N., (2014), "Mechanical Properties of Concrete Containing Roof Tiles Subjected to Elevated Temperatures," International Journal of Innovative Research in Advanced Engineering, 1(8), 255-261.

Naus, D. J., (2006), "The Effect of Elevated Temperature on Concrete Materials and Structures- A Literature Review," U.S. Nuclear Regulatory Commission, 1(1), 166 pages.

Parekh, D.N., and Modhera, C.D., (2011), “Assessment of Recycled Aggregate Concrete,” Journal of Engineering Research and Studies, 2(1), 9 pages.

Salau, M. A., Oseafiana, O. J., and Oyegoke, T. O., (2015), "Effects of Elevated Temperatureon Concrete With Recycled Coarse Aggregate," $2^{\text {nd }}$ International Conference on Innovative Materials, Structure and Technologies, 8 pages.

Tabsh, S. W., and Abdlfatah, A. S., (2009), Influenced of Recycled Concrete Aggregates on Strength Properties of Concrete, Cement and Concrete Research, 23 (2), 1163- 1167.

Vieira, J. P. B., Correia, J. R., and de Brito, J., (2011), "Post-Fire Residual Mechanical Properties of Concrete Made With Recycled Concrete Coarse Aggregates," Cement and Concrete Research Journal, 41(5), 533-541.

Young, P. C., Teo, D.C. L., (2009), "Utilisation of Recycled Aggregate as Coarse Aggregate in Concrete" E- Journal of Civil Engineering, 1(1), 6 pages. 